\title{
Impact of Inheritance and Housing Wealth on Retirement Decision*
}

\author{
Sid Ali Amedah, Maxime Fougère \\ Employment and Social Development, Gatineau, Canada \\ Email: sidali.amedah@hrsdc-rhdcc.gc.ca, maxime.fougere@hrsdc-rhdcc.gc.ca
}

How to cite this paper: Amedah, S.A. and Fougère, M. (2017) Impact of Inheritance and Housing Wealth on Retirement Decision. Open Journal of Social Sciences, 5, 1 12.

https://doi.org/10.4236/jss.2017.57001

Received: April 31, 2017

Accepted: June 30, 2017

Published: July 3, 2017

Copyright $\odot 2017$ by authors and Scientific Research Publishing Inc. This work is licensed under the Creative Commons Attribution International License (CC BY 4.0).

http://creativecommons.org/licenses/by/4.0/ (c) (i) Open Access

\begin{abstract}
This paper proposes to find how wealth shocks such as inheritances and housing wealth impact retirement behaviour using cross-sectional micro data from the Canadian Survey of Financial Security. Estimation of wealth impact on retirement decision is challenging since wealth and retirement decision may be endogenously determined. We found no evidence that housing wealth impacts retirement decision suggesting that individuals are correctly anticipating future housing wealth and adjusting their labour market behaviour accordingly. However, the data supports the hypothesis that receiving an inheritance significantly increases the retirement hazard, which may indicate the existence of some financial constraints.
\end{abstract}

\section{Keywords}

Inheritance, Housing Wealth, Retirement Hazard, Financial Security

\section{Introduction}

The aging population is raising some issues for Canada, especially concerning implications related to the adequacy of the retirement income system for the middle class. Two potential monetary sources that may improve the retirement outlook for baby boomers are inheritances and housing wealth.

Based on the 2012 Survey of Financial Security, about 24\% of Canadian households received inheritances with an accumulated value of $\$ 753$ billion representing a median value of $\$ 33,656$. Furthermore, about $71 \%$ of Canadians own their houses for a total value of $\$ 8170$ billion representing a median value of $\$ 325,000$.

Retirement behaviours have direct implications for transfer programs such as *The views expressed in this report are those of the authors and not necessarily those of Employment and Social Development Canada. We would like to thank Patrick Bussière, Yves Carrière, Benoît-Paul Hébert, Alexandre Laurin, René Morissette and Tammy Schirle for useful comments. Finally, a special thanks to Krishan Suki Abeysekera and Jean-Michel Billette; for providing timely assistance with respect to data access to Statistics Canada's Research Data Centre. 
pensions programs or tax policies. For example, many policy options such as changes to retirement age or to public pension replacement rate involve either implicit or explicit transfers of wealth, which creates incentives that affect retirement decisions, through wealth effects.

According to economic theory, leisure is a normal good and thus any increase in non-labour income through inheritance receipt or gain in housing wealth, everything else equal, is expected to reduce the lifetime labour supply of utilitymaximizing individuals. In fact, a large wealth shock may induce these individuals to completely withdraw from the labour market, depending on the size of the wealth effect.

This classical theory of positive wealth effects has been widely tested in the literature using different instrumental variables (lotteries, inheritances and gifts). While findings in Ashenfelter and Heckman [1] support this theory, Moffit [2] examines the incentives effect of US welfare system on labour supply and finds negative effects for female heads family.

Although there is a large empirical literature, there remains limited consensus on the effect and magnitude of the wealth effect on labour supply. Imbens et al. [3] show that unearned income reduces labour earnings, with larger effects for individuals aged 55 to 65 years old. Using a large sample of lottery players in Sweden Cesarini et al. [4] finds that winning a lottery prize immediately and permanently reduces labour earnings. Using the stock market prices variation, Coile et al. [5] find no effect of stock market wealth variation on retirement behaviour, while Coronado et al. [6] and Sevak [7] find that stock market unanticipated wealth leads workers to retire earlier. Ratcliffe and Smith [8] find that an increase in stock prices or annuity rates increases the probability of retirement.

Holtz-Eakin et al. [9] and Joulfaian and Wilhelm [10] examine the effect of inheritance receipt on labour supply in USA. The former considers only younger workers and find that large inheritances decrease a person's labour supply. The latter focuses on older workers and finds that inheritances do not lead to large reduction in the labour supply of men and married women.

Brown et al. [11] provide new evidence on how wealth shocks influence retirement behaviour; inheritance is associated with a significant increase of the probability of retirement. Bloeman [12] empirically analyzed the effect of wealth on the retirement and concluded that there is a positive effect of wealth on early retirement.

Only a few studies have been conducted on the micro-impact of housing wealth on labour supply and no consensus has emerged. Henley [13] measures the impact of real housing wealth gain on labour supply and finds that observed adjustments in working hours are only partial responses. Bijlsma [14] estimates the impact of housing wealth shock on household savings and finds no significant effect for older homeowners.

Farnham and Sevak [15] empirically estimate the impact of housing wealth on retirement timing and find that wealth effects are present. Fisher et al. [16] argue that housing wealth has no impact on consumption. Morris [17] also argues that 
the rise in housing costs offsets the increase of market prices; there is no significant effect of housing wealth.

To our knowledge, no studies have examined the effect of inheritance or housing wealth on retirement behaviour using Canadian micro data. Our study extends the literature by exploring the impact of financial and non-financial wealth shocks on Canadians' retirement behaviours using data from the 2012 Survey of Financial Security (SFS). The SFS contains information on Canadians wealth such as inheritances and housing and also includes retrospective information about respondents' historical events such as age at retirement, and inheritance and housing wealth. Since the only duration variable available is-retirement age - which is available in interval censored form (yearly intervals), we consider a discrete-time hazard model which is presented in the next section.

Estimation of wealth impact on retirement decision is challenging since wealth and retirement decision may be endogenously determined. Inheritance receipt and variation in housing values are considered here as two sources of exogenous variation that provides a useful way of estimating the effect of wealth shocks on retirement decision.

Our results clearly indicate that inheritance recipients have significantly higher retirement hazard compared to non-recipients, which may indicate the existence of some financial constraints. Therefore, even if an individual has less uncertainty about saving inadequately and hence knows additional savings are desired, financial constraints may prevent additional contributions to saving.

We did not find evidence that housing wealth impact retirement decision suggesting that individuals are correctly anticipating future housing wealth and adjusting their labour market behaviour accordingly.

Although inheritances and housing wealth are important in aggregate, the timing and the effective amount of the receipts of any particular household are highly uncertain and subject to fluctuations in the stock and housing markets and thus are not a substitute for adequate saving for retirement.

This paper proceeds as follows: Section 2 presents the modelling framework of retirement decision; the data and empirical strategy are presented in Section 3; estimation results are provided in Section 4; and the paper concludes with some remarks in Section 5.

\section{Modelling Retirement Decision}

Applications of survival approaches (or Duration models) to model retirement decision were first carried out by Diamond and Hausman [18] and Wise [19]. Both works relied on hazard models used to model the unemployment durations by Lancaster [20].

The major characteristics of a survival model are:

1) The dependent variable represents the "waiting time" until the occurrence of a well-known event in our case "time to retirements" is considered as a continuous random variable;

2) Observations are censored, i.e. for some individuals the retirement event has 
not occurred yet when the data are collected;

3) And there are observed exogenous explanatory variables which affect the waiting time or the time to retirement.

Since the retirement process occurs in continuous time but time to retirement spell lengths are available only in interval censored form, the discrete time version of the proportional hazard model of Prentice-Gloeckler [21] is considered here.

\section{Modeling Framework}

Let $T$ denote a discrete random variable indicating the time to retirement which is observed at discretely defined points in time, $t_{j}$. The unconditional probability of retirement at time or age $t_{j}$ is given by the following probability density function:

$$
f\left(t_{j}\right)=P\left(T=t_{j}\right)
$$

The survivor function or the probability of staying in the state of employment beyond age $t_{j}$ is:

$$
S\left(t_{j}\right)=P\left(T \geq t_{j}\right)=\sum_{k \geq j} f\left(t_{k}\right)
$$

where $k$ denotes a failure time or the point of time where retirement occurs. In other words, the probability of staying in the state of employment beyond $t_{j}$ is simply the summation of the probabilities of retiring at any point after $t_{j}$.

Now, we define the discrete-time hazard for individual $i$ at time $t_{j}$ as the conditional probability of retiring at that time given that person $i$ has stayed employed to that point, so that:

$$
h_{i}\left(t_{j} \mid X_{i}\right)=P\left(T=t_{j} \mid T \geq t_{j}, X_{i}\right)
$$

where $X_{i}$ is a vector of observed covariates for person $i$. Thus the discrete-time hazard is the conditional probability of retirement given that person $i$ stayed employed up to that point in time.

Based on Bayes theorem and from (3) we have:

$$
h_{i}\left(t_{j} \mid X_{i}\right)=\frac{f\left(t_{j}\right)}{S\left(t_{j}\right)}
$$

which demonstrates that the risk of retirement occurrence is equivalent to the ratio of the probability of retirement to the probability of staying in the state of employment.

Next, we specify how this discrete-time hazard depends on time and explanatory variables. Assume that the data are generated by a continuous hazard model or, more precisely, the most widely used functional form called proportional hazards model:

$$
h_{i}\left(t_{j} \mid X_{i}\right)=h_{0}\left(t_{j}\right) \cdot \exp \left\{X_{i}^{\prime} \beta\right\}
$$

where $h_{0}\left(t_{j}\right)$ is the baseline hazard function which may take a parametric or non-parametric form and $\beta$ is a vector of unknown parameters to be estimated. Holford [22] and Prentice and Gloeckler [21] show that the corresponding dis- 
crete-time hazard function is given by:

$$
h_{i}\left(t_{j} \mid X_{i}\right)=1-\exp \left[-\exp \left(\alpha_{j}+X_{i}^{\prime} \beta\right)\right]
$$

where $\alpha_{j}$ is the complementary log-log transformation of the baseline hazard. Solving for the hazard for individual $i$ at time $t_{j}$ we obtain the complementary $\log$-log transformation that yields a linear function of the model parameters:

$$
\log \left(-\log \left(1-h_{i}\left(t_{j} \mid X_{i}\right)\right)\right)=\alpha_{j}+X_{i}^{\prime} \beta
$$

The conventional Maximum Likelihood estimation and inference for this model is straightforward.

\section{Data and Empirical Strategy}

We use Canadian cross-sectional micro data from the Survey of Financial Security (SFS) of $2012^{1}$, which contains respondents' characteristics such as age, family status, marital status, health situation, and also retrospective information about respondents' historical events such as age at retirement, inheritance receipt and timing, housing wealth, and change in marital status. SFS is a unique source of exogenous variation in financial and housing wealth. Furthermore, retirement age and inheritance timing variables make possible the estimation of a dynamic model that captures the effect of wealth shocks on retirement behaviour. Since the information on inheritance receipt is only available at the household level we limit our sample to the major income earners.

An important issue in modelling retirement decision is defining "retirement". For the purposes of this paper, we rely on a self-reported measure of retirement, where respondents aged 45 and over were asked whether they ever retired or not, and at what age, if the answer was "yes". In the data sample about $38.1 \%$ of major income earners have self-reported they ever retired.

For our analysis, we dropped individuals who were out of the labour market for a long time, i.e. those who declared their status as "Long term illness or disability", "No main activity", or "Keeping house".

Since the only duration variable available is-retirement age-which is available in interval censored form (yearly intervals), we model retirement duration as a discrete-time hazard model, or more specifically, the hazard of exiting the state of employment is modelled using a discrete-time hazards model given by Equation (7).

The objective is to compare the retirement hazard or the conditional probability of retirement between inheritances recipients and non-recipients while controlling for inheritance receipt timing. ${ }^{2}$ To estimate the impact of housing wealth

${ }^{1}$ We use the Masterfile data file accessed through the Federal Research Data Centre of Statistics Canada, which contains all responses by each respondent, recorded in the format specified on the questionnaire.

${ }^{2}$ Inheritance receipt is measured as a dummy variable for any inheritance amount received over $\$ 25,000$. To control for inheritance timing we consider a continuous variable defined as the difference between retirement age and the age of receipt of the most important inheritance. Different model specifications were compared using LR tests if nested, otherwise BIC and AIC are considered. Model specifications considered here include controlling for Inheritances timing which is the only feasible option here. 
on retirement decision, housing wealth is instrumented using the variation in the home value which is exogenously driven by housing markets. The variation in the home value is computed as the difference between the current value minus the present value of the purchase price. Other covariates include individual characteristics such as gender, educational attainment, health status, immigration status, and existence of workplace pension plan. Family responsibilities influence the labour market participation for women which might impact their decision to retire. Years of education, especially postsecondary education, make a difference in the economic wellbeing of individuals in terms of earnings and retirement savings which, subsequently, influence their retirement decision. Furthermore, having a workplace pension plan may create incentives to early retirement, as may having a work limitation associated with health issues. Similarly, immigrants who are late joining the labour market may postpone retirement due to the lack of retirement savings.

The baseline hazard is modelled here as a standard Weibull distribution ${ }^{3}$ which allows the hazard of retirement to either rise monotonically with time, fall monotonically with time, or to be constant.

Lancaster [20] shows that not accounting for unobserved heterogeneity may lead to biased estimates of the baseline hazard as well as of the regression coefficients. To control for the unobserved differences between individuals in the available data, we introduce a positive-valued random variable, $v_{i}$, into the discrete-time hazard specification given by (7):

$$
\log \left(-\log \left(1-h_{i}\left(t_{j} \mid X_{i}\right)\right)\right)=\alpha_{j}+X_{i}^{\prime} \beta+u_{i}
$$

where $u_{i}=\log v_{i}$.

Equation (8) raises identification problem for $u_{i}$ since there are as many individual effects as individuals in the data sample. If we suppose that $u_{i}$ follows a distribution that can be summarized in terms of a few key parameters as proposed by Meyer [23] $]^{4}$, then the survivor function and likelihood function will have a closed forms and it becomes possible to estimate those parameters with the available data. Here it is supposed that $u_{i}$ is a Gamma ${ }^{5}$ distributed random variable assumed to be independent of $X_{i}^{\prime}$, with unit mean and variance $\sigma^{2}$.

Following Jenkins [24] the data is reorganized so that the unit of analysis is changed from the individual to the time at risk of retirement event. For each person, there are as many data rows as there are time intervals at risk of retirement occurring for each person. This unbalanced panel data set allows simplifying the likelihood based estimation to standard estimation for a binary outcome. See Jenkins [24] for more details on the estimation method.

Estimation of wealth impact on retirement decision is challenging since wealth and retirement decision may be endogenously determined. Inheritance ${ }^{3}$ This is a more general flexible function that includes other distributions such as the exponential distribution as a special case.

${ }^{4}$ In this case the survivor function and hence the likelihood function will have a closed form. For more details see Jenkins [24].

${ }^{5}$ The gamma distribution is a shape shifter that can assume a range of shapes, from exponential to normal. This flexibility results from the fact that gamma distribution has two shape parameters. 
receipt and variation in housing values represent two sources of exogenous variation that provides a useful way of estimating the effect of wealth shocks on retirement decision.

\section{Results}

Descriptive analyses and maximum likelihood estimations results of the discretetime hazard model are presented in this section.

\subsection{Descriptive Analysis}

Canadian households reported they received a total cumulative value of $\$ 754$ billion in inheritances over their lifetime at the time of the survey. Individuals aged 45 and over accounted for the majority of inheritance recipients, about $68 \%$. The mean and the median inheritance received are respectively $\$ 109,198$ and $\$ 33,656$. However, given that the distribution of inheritances is highly rightskewed, i.e. some recipients obtained very high value inheritances; these parameters are not truly representative of the distribution. As shown in Table 1, total value, mean, and median inheritances increase with age.

Table 2 indicates the relative distribution of inheritances among different age groups. Overall, about $25 \%$ of Canadian households had received any inheritance over their lifetime at the time of the survey. This percentage increases with age, indicating that older age groups in the sample are more likely to receive an inheritance compared with younger age groups.

As shown in Table 3 the percentage of retired individuals by inheritance receipt status does not clearly indicate whether inheritance recipients are more likely to retire earlier than non-recipients. This is due to the fact that we are not controlling for potential confounding factors such as work limitation or educational attainment and more importantly retirement timing.

Although, the distribution of inheritances has some redistributive effect, Table 4 shows that this redistributive effect is very unequal since the richest $30 \%$ of households receive $50 \%$ of the total value of inheritances. As indicated by Table 5 , about $71 \%$ of Canadian households own their homes, but only $31 \%$ are mortgage free. While, ownership increases with age, about $15 \%$ of the major income earners who are 65 years old or over still have mortgage to pay. The mean and

Table 1. Mean and median and total value of cumulative inheritance received by age group (in \$2012).

\begin{tabular}{cccc}
\hline Age Group & Mean $(\$)$ & Median $(\$)$ & Total Value (\$000s) \\
\hline$<45$ & 89,804 & 26,665 & $202,699,889$ \\
$45-54$ & 99,490 & 28,825 & $108,229,228$ \\
$55-64$ & 122,150 & 43,875 & $200,910,358$ \\
$65+$ & 126,451 & 43,231 & $242,111,501$ \\
All & 109,198 & 33,656 & $753,950,978$ \\
\hline
\end{tabular}

Source: 2012 Survey of Financial Security. Amounts are expressed in \$2012. 
Table 2. Distribution of inheritance receipts by age group.

\begin{tabular}{ccccccc}
\hline $\begin{array}{c}\text { Age } \\
\text { Group }\end{array}$ & $\begin{array}{c}\text { Total Number } \\
\text { of Individuals }\end{array}$ & NO inheritance & $\begin{array}{c}\text { Number receiving } \\
\text { ANY inheritance }\end{array}$ & $\begin{array}{c}\text { Share receiving } \\
\text { inheritance of } \$ 25,000 \text { and } \\
\text { over }\end{array}$ & $\begin{array}{c}\text { Share receiving inheritance } \\
\text { of } \$ 50,000 \text { and over }\end{array}$ & $\begin{array}{c}\text { Share receiving } \\
\text { inheritance of } \$ 100,000 \\
\text { and over }\end{array}$ \\
\hline$<45$ & $13,792,262$ & $11,493,321$ & $2,298,941$ & $8.8 \%$ & $6.2 \%$ & $3.4 \%$ \\
$45-54$ & $4,964,736$ & $3,866,429$ & $1,098,307$ & $12.1 \%$ & $8.6 \%$ & $5.8 \%$ \\
$55-64$ & $4,744,840$ & $3,076,608$ & $1,668,232$ & $21.9 \%$ & $17.1 \%$ & $11.7 \%$ \\
$65+$ & $4,938,756$ & $2,971,927$ & $1,966,829$ & $26.3 \%$ & $19.1 \%$ & $13.4 \%$ \\
All & $28,440,594$ & $20,955,842$ & $7,032,309$ & $14.6 \%$ & $10.7 \%$ & $6.9 \%$
\end{tabular}

Source: 2012 Survey of Financial Security. Amounts are expressed in \$2012.

Table 3. Share retired (\%) by inheritance receipt and amount.

\begin{tabular}{|c|c|c|c|c|}
\hline Age Group & $\begin{array}{c}\text { Total Share Retired } \\
(\%)\end{array}$ & $\begin{array}{c}\text { Share Retired - No Inheritance } \\
(\%)\end{array}$ & Share Retired - Any Inheritance & $\begin{array}{c}\text { Share Retired -Inheritance } \\
\text { of } \$ 25,000 \text { or over }\end{array}$ \\
\hline $45-54$ & $3.4 \%$ & $69.5 \%$ & $30.5 \%$ & $13.1 \%$ \\
\hline $55-64$ & $30.4 \%$ & $56.1 \%$ & $43.9 \%$ & $29.5 \%$ \\
\hline $65+$ & $80.3 \%$ & $59.2 \%$ & $40.8 \%$ & $26.8 \%$ \\
\hline
\end{tabular}

Source: 2012 Survey of Financial Security. Amounts are in real \$2012 dollars. Note: Share of individuals retired by amount of inheritance censored due to small sample size.

Table 4. Mean, Median and Total Inheritance Received by adjusted ${ }^{6}$ income deciles, 2012.

\begin{tabular}{ccccc}
\hline Decile & Mean & Median & Total & \% of Total \\
\hline 1 & 100,658 & 25,514 & $45,570,574,297$ & $6.0 \%$ \\
2 & 58,009 & 18,552 & $32,671,065,711$ & $4.3 \%$ \\
3 & 83,795 & 30,450 & $57,081,220,859$ & $7.6 \%$ \\
4 & 71,245 & 28,435 & $44,904,094,087$ & $6.0 \%$ \\
5 & 92,291 & 42,899 & $64,100,175,044$ & $8.5 \%$ \\
6 & 94,635 & 32,069 & $61,092,762,244$ & $8.1 \%$ \\
7 & 91,366 & 28,976 & $72,914,441,382$ & $9.7 \%$ \\
9 & 140,454 & 39,902 & $104,013,633,350$ & $13.8 \%$ \\
10 & 134,579 & 46,569 & $100,341,335,635$ & $13.3 \%$ \\
All & 179,764 & 45,040 & $171,261,675,015$ & $22.7 \%$ \\
\end{tabular}

Source: 2012 Survey of Financial Security. Amounts are in $\$ 2012$.

Table 5. Distribution of households by home ownership status, 2012.

\begin{tabular}{|c|c|c|c|c|c|c|}
\hline \multirow{2}{*}{ Age Group } & \multicolumn{2}{|c|}{ Own without Mortgage } & \multicolumn{2}{|c|}{ Own with Mortgage } & \multicolumn{2}{|c|}{ Do not own } \\
\hline & Number & $\%$ & Number & $\%$ & Number & $\%$ \\
\hline$<45$ & $2,049,657$ & $14.9 \%$ & $6,789,141$ & $49.2 \%$ & $4,953,464$ & $35.9 \%$ \\
\hline $45-54$ & $1,434,372$ & $28.9 \%$ & $2,413,289$ & $48.6 \%$ & $1,117,074$ & $22.5 \%$ \\
\hline $55-64$ & $2,270,483$ & $47.9 \%$ & $1,458,018$ & $30.7 \%$ & $1,016,339$ & $21.4 \%$ \\
\hline $65+$ & $3,067,105$ & $62.1 \%$ & 727,710 & $14.7 \%$ & $1,143,941$ & $23.2 \%$ \\
\hline All & $8,821,617$ & $31.0 \%$ & $11,388,159$ & $40.0 \%$ & $8,230,818$ & $28.9 \%$ \\
\hline
\end{tabular}

Source: 2012 Survey of Financial Security.

${ }^{6}$ Family income is adjusted by family size. 
the median of the home value expressed in $\$$ (2012) are respectively $\$ 404,242$ and $\$ 325,000$.

\subsection{Estimation Results}

We estimated different model specifications. In each specification we estimate the model with and without unobserved heterogeneity given respectively by Equations ((8) and (7)). The likelihood ratio test suggests statistically significant unobserved heterogeneity for the retained model. The parameters estimates of this model specification represented by (8) are reported in the first column of Table 6. The sign of the estimate of the duration dependence parameter reveals that the retirement hazard or the conditional probability to retire increases with age.

Clearly, according to the model parameters estimates, the retirement hazard rate or the conditional probability to retire for inheritance recipients is about $20 \%$ higher compared to non-recipients. Graphic 1 shows the predicted survivor function or the estimated conditional probability of staying in the labor market beyond a given age, indicating that inheritances recipients are more likely to retire at earlier ages compared to non-recipients. This suggests that individuals are not correctly anticipating future inheritances.

Housing wealth has no significant effect on the conditional probability to retire. When the inverse hyperbolic sine transformation was applied to the housing wealth to address the excess of skewedness in this variable, we obtained a very small significant positive impact, suggesting that individuals are correctly anticipating future housing wealth and adjusting their labour market behaviour accordingly.

Women have a higher conditional probability of retirement than men with a retirement hazard $27 \%$ higher. Couples households have also a higher retirement hazard compared to unattached households. Having postsecondary education increases the retirement hazard, by about $7 \%$. Work limitation due to health is-

Table 6. Discrete-time hazard ML parameters estimates.

\begin{tabular}{cccc}
\hline Factor & Coefficient & Std. Err. & Hazard ratio \\
\hline Number of years above age 45 (in log) & $9.75^{* * *}$ & 0.164 & $17,191.4$ \\
Received an Inheritance of at least $\$ 20,000$ & $0.18^{* * *}$ & 0.042 & 1.20 \\
Female & $0.24^{* * *}$ & 0.038 & 1.27 \\
Couple Households & $0.20^{* * *}$ & 0.043 & 1.22 \\
Postsecondary Education & $0.07^{*}$ & 0.039 & 1.07 \\
Immigrant & $-0.26^{* * *}$ & 0.047 & 0.77 \\
Work limitation & $1.17^{* * *}$ & 0.041 & 3.22 \\
Housing wealth & $-4.06 \mathrm{E}-08$ & $6.97 \mathrm{E}-08$ & 1.00 \\
Workplace pension & $0.62^{* * *}$ & 0.038 & 1.85 \\
Constant & $-43.67^{* * *}$ & 0.048 & $1.09 \mathrm{E}-19$ \\
\hline
\end{tabular}

Source: 2012 Survey of Financial Security; Notes: ${ }^{\star * *}$ p-value $<0.01 ;{ }^{\star}$ p-value $<0.1$. 


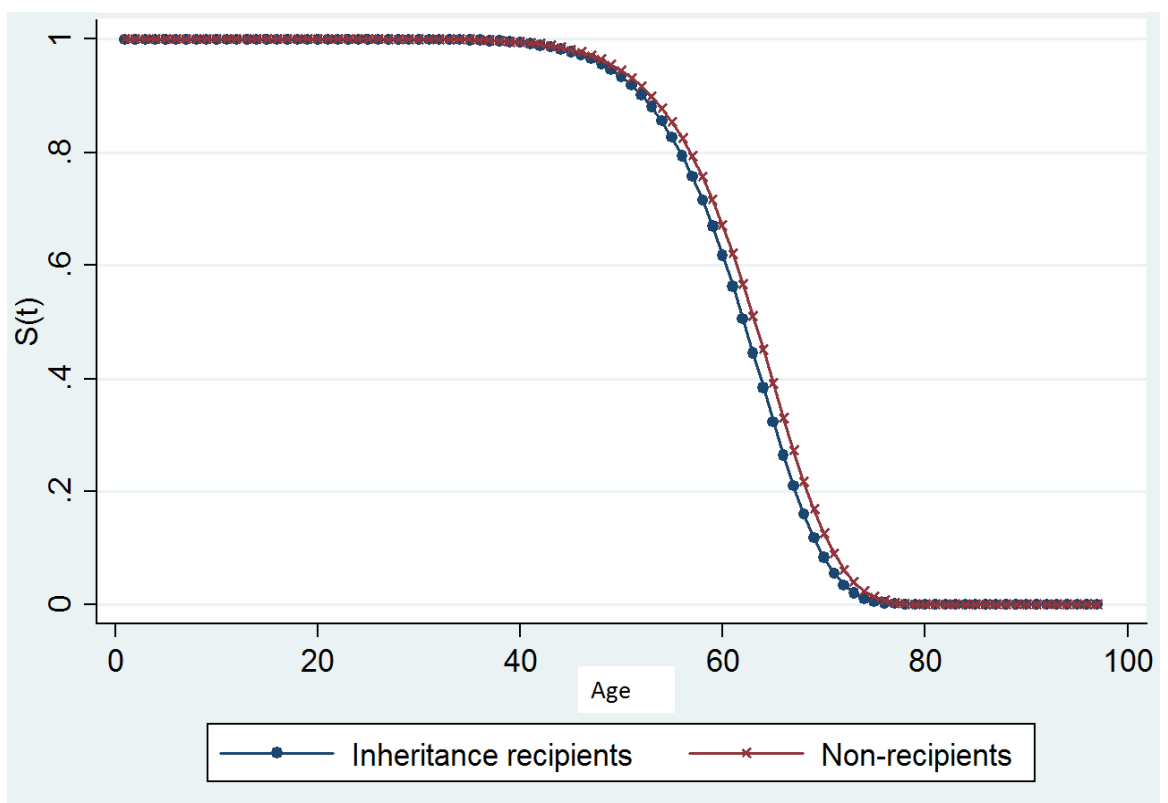

Graphic 1. Estimated conditional probability of staying in the labour market beyond a given age.

sues is associated with a huge increase in the retirement hazard, about 3.2 times more than those without any work limitations. The retirement hazard for recent immigrants is $23 \%$ lower than Canadian born; and having a workplace pension increases the retirement hazard by about $85 \%$.

\section{Conclusion}

The objective of this paper is to develop an empirical foundation for understanding wealth effects, i.e. how wealth shocks such as inheritances and housing wealth impact retirement behaviour. Understanding wealth effects on retirement behaviour is of key interest to social policymakers. For example, many policy options such as changes to retirement age or change to public pension replacement rate involve either implicit or explicit transfers of wealth which creates incentives that affect retirement decisions, through wealth effects.

Estimation of wealth impact on retirement decision is challenging since wealth and retirement decision may be endogenously determined. Inheritance receipt and variation in housing values represent two sources of exogenous variation that provides a useful way of estimating the effect of wealth shocks on retirement decision. They would also constitute two potential monetary sources that may improve the retirement outlook for individuals at retirement.

Using the Survey of Financial Security our paper provides new evidence on the role of inheritance receipt and hosing wealth on retirement decision. We estimate the impact of inheritance and housing wealth shocks on the retirement hazard.

We found no evidence that housing wealth impacts retirement decision suggesting that individuals are correctly anticipating future housing wealth and adjusting their labour market behaviour accordingly. However, the data supports 
the hypothesis that receiving an inheritance significantly increases the retirement hazard, which may indicate the existence of some financial constraints. Therefore, even if an individual has less uncertainty about saving inadequately and hence knows additional savings are desired, financial constraints may prevent additional contributions to saving.

Although inheritances and housing wealth are important in aggregate, the timing and amount of the receipts of any particular household are highly uncertain. Furthermore, inheritance and housing wealth are also subject to important fluctuations in the stock and housing markets and thus are not a substitute for adequate saving for retirement, especially for the middle class.

Finally, our results indicate that women have a higher conditional probability of retirement than men. Couples households have also a higher retirement hazard compared to unattached households. Individuals with a postsecondary education or a workplace pension plan have a higher conditional probability to retire. Work limitation due to health issues is associated with a huge increase of the retirement hazard. Recent immigrants have a significantly lower probability of retirement.

\section{References}

[1] Ashenfelter, O. and Heckman, J. (1974) The Estimation of Income and Substitution Effects in a Model of Family Labor Supply. Econometrica, 42, 73-86. https://doi.org/10.2307/1913686

[2] Moffit, R. (1992) Incentive Effects of the U.S. Welfare System: A Review. Journal of Economic Literature, 30, 1-61.

[3] Imbens, G., Rubin, D.B. and Sacerdote, B.I. (2001) Estimating the Effect of Unearned Income on Labor Earnings, Savings, and Consumption: Evidence from a Survey of Lottery Players. American Economic Review, 91, 778-794. https://doi.org/10.1257/aer.91.4.778

[4] Cesarini, D., Lindqvist, E., Notowidigdo, M.J. and Ostling, R. (2013) The Effect of Wealth on Household Labour Supply: Evidence from Swedish Lotteries Working Paper, University of Berkeley.

[5] Coile, C.C. and Levine, P.B. (2006) Bulls, Bears, and Retirement Behavior. Industrial and Labor Relations Review, 59, 408-429. https://doi.org/10.1177/001979390605900304

[6] Coronado, J. and Perozek, M. (2003) Wealth Effects and the Consumption of Leisure: Retirement Decisions During the Stock Market Boom of the 1990s, Board of Governors of the Federal Reserve System, Finance and Economics Discussion Series \#2003-20.

[7] Sevak. P. (2002) Wealth Shocks and Retirement Timing: Evidence from the Nineties, Michigan Retirement Research Center Working Paper 2002-027.

[8] Ratcliffe, D.R. and Smith, S. (2010) Booms, Busts and Retirement Transitions. Centre for Market and Public Organisation, University of Bristol.

[9] Holtz-Eakin, D., Joulfaian, D. and Harvey S.R. (1993) The Carnegie Conjecture: Some Empirical Evidence. Quarterly Journal of Economics, 108, 413-435. https://doi.org/10.2307/2118337

[10] Joulfaian, D. and Wilhelm, M.O. (1994) Inheritance and Labour Supply. Journal of 
Human Resources, 29, 1205-1234. https://doi.org/10.2307/146138

[11] Brown, J., Coile, C. and Weisbenner, S. (2011) The Effect of Inheritance Receipt on Retirement. National Bureau of Economic Research, Cambridge.

[12] Bloeman, H.G. (2010) The Effect of Private Wealth on the Retirement Rate: An Empirical Analysis. Economica, 78, 637-655. https://doi.org/10.1111/j.1468-0335.2010.00845.x

[13] Henley, A. (2004) House Price Shocks, Windfall Gains and Hours of Work: British Evidence. Oxford Bulletin of Economics and Statistics, 66, 439-456. https://doi.org/10.1111/j.1468-0084.2004.00088.x

[14] Bijlsma, I. (2013) Changes in Household Behaviour after a Housing Wealth Shock. MSc Thesis, Network for Studies on Pensions, Aging and Retirement, 2013-024.

[15] Farnham, M. and Sevak, P. (2007) Housing Wealth and Retirement Timing. Retirement Research Center, Michigan.

[16] Fisher, L.A., Glenn, O. and Graham, M.V. (2005) Housing Booms, Non-Financial Wealthand Consumption: Lessons from the Australian Experience. University of Victoria, Victoria.

[17] Morris, E.D. (2006) Examining the Wealth Effect from Home Price Appreciation. University of Michigan, Ann Arbor.

[18] Diamond, P.A. and Hausman, J.A. (1984) Individual Retirement and Savings Behavior. Journal of Public Economics, 23, 81-114.

[19] Wise, S.L. (1985) The Development and Validation of a Scale Measuring Attitudes toward Statistics. Educational and Psychological Measurement, 45, 401-405.

[20] Lancaster, T. (1990) The Econometric Analysis of Transition Data. Cambridge University Press, Cambridge.

[21] Prentice, R.L. and Gloeckler, L.A. (1978) Regression Analysis of Grouped Survival Data with Application to Breast Cancer Data. Biometrics, 34, 57-67.

https://doi.org/10.2307/2529588

[22] Holford, T.R. (1976) Life Tables with Concomitant Information. Biometrics, 32, 587-597. https://doi.org/10.2307/2529747

[23] Meyer, B.D. (1990) Unemployment Insurance and Unemployment Spells. Econometrica, 58, 757-782. https://doi.org/10.2307/2938349

[24] Jenkins, S.P. (1995) Easy Estimation Methods for Discrete-Time Duration Models'. Oxford Bulletin of Economics and Statistics, 57, 129-138.

https://doi.org/10.1111/j.1468-0084.1995.tb00031.x 
Submit or recommend next manuscript to SCIRP and we will provide best service for you:

Accepting pre-submission inquiries through Email, Facebook, LinkedIn, Twitter, etc. A wide selection of journals (inclusive of 9 subjects, more than 200 journals)

Providing 24-hour high-quality service

User-friendly online submission system

Fair and swift peer-review system

Efficient typesetting and proofreading procedure

Display of the result of downloads and visits, as well as the number of cited articles Maximum dissemination of your research work

Submit your manuscript at: http://papersubmission.scirp.org/

Or contact jss@scirp.org 